TITLE: FORMATION OF NEW PROPERTY RIGHTS ON GOVERNMENT LAND THROUGH INFORMAL CO-MANAGEMENT: CASE STUDIES ON COUNTRYSIDE GUERILLA GARDENING

AUTHOR'S NAME: HUNG, HOLVERT ${ }^{1}$ Department of Real Estate and Construction Department, The University of Hong Kong

AFFILIATION ADDRESS: $5^{\text {th }}$ FLOOR, KNOWLES BUILDING, DEPARTMENT OF REAL ESTATE AND CONSTRUCTION, THE UNIVERSITY OF HONG KONG, POKFULAM, HONG KONG

CORRESPONDING AUTHOR: HUNG, HOLVERT

EMAIL ADDRESS: hholvert@hku.hk

1 Flat 2H, Block 4, Site 7, Cotton Tree Mansion, Whampoa Garden, Hung Hom, Kowloon Hong Kong SAR 


\title{
FORMATION OF NEW PROPERTY RIGHTS ON GOVERNMENT LAND THROUGH INFORMAL CO-MANAGEMENT: CASE STUDIES ON COUNTRYSIDE GUERILLA GARDENING
}

\begin{abstract}
:
Extant research on guerilla gardening, defined as the unauthorized cultivation of land belonging to another, has hitherto focused on public space in urban areas, neglecting those that occur in rural settings. This rural land policy study examines a form of guerilla gardening in the countryside in Hong Kong, carried out by specific walker communities who routinely do early morning walks. Most of the gardens they have cultivated have become part of country park protected areas. This study identifies five phases of land use status evolution undergone by these morning walkers' gardens (MWG), from the time the phenomenon of guerilla gardening in the countryside began in the 1960s to recent times, illustrating the role of land use change in enabling squatters with a degree of property rights by way of informal land resource co-management. Through the three case studies presented in this article, it is argued that MWGs can represent the emergence of incipient forms of natural resource co-management in Hong Kong. This study emphasizes the important role of resource user leadership in enhancing the land use value of land in itself and for the wider community. Some recommendations are provided to enhance resource user participation in land resource management.
\end{abstract}

Keywords: guerilla gardening; morning walker; land use change; property rights formation; co-management; resource user leadership

\section{Introduction}

While MWGs 'founded' in the hills and mountains of Hong Kong were originally seen as illegal and were therefore subjected to control and even demolishment, they have become one of the recreational site facilities provided by the government in country parks. Based on the initial study commissioned by the British colonial government in Hong Kong for the introduction of a system of protected areas, MWGs were clearly not foreseen as some of the recreational site facilities to be provided in country parks (Talbot, 1965). MWGs are officially called as such, because they were originally 'founded' and cultivated by specific walker communities who walk the hills and mountains between six and nine every morning. Compared to walkers in general, who walk the hills and mountains in the morning or at other times of the day, these guerilla-gardening walker communities are in the minority. The creation of protected areas in Hong Kong was aimed at conserving biodiversity and wildlife and controlling outdoor recreational and nature-based activities in which city dwellers began to develop interest in the 1960s (Jim, 1986). Another objective was the control of 
unlawful occupation of government land including private gardens cultivated by morning walkers. According to early drafts of the Country Park Bill, the unauthorized occupation of government land implies both squatter settlements and 'private' gardens. ${ }^{1}$ In Hong Kong laws, the unauthorized occupation of land is defined as to illegally "use, inhabit, be in possession of, enjoy, erect or maintain a structure on or over, and place or maintain anything on, land” (Land (Miscellaneous Provisions) Ordinance, Cap. 28). These private gardens present an interesting form of guerilla gardening, which have eventually become incorporated into country park land use planning known as MWG.

This paper offers at least four contributions. First, the study examines guerilla gardening in an Asian context, thus it contributes to the body of academic literature which has largely focused on the American, European, and more recently Australian contexts. Second, the paper introduces a phenomenon unique to Hong Kong, that is, countryside guerilla gardening. This unique spatial phenomenon extends the concept of guerilla gardening beyond urban areas. Third, this paper uses the concept of co-management to describe the land use status evolution of MWGs in Hong Kong country parks. Co-management offers insights into the relationship between user-groups and the state with respect to small-scale natural resource units within protected areas. Fourth, although the partnership arrangement described in this paper is still in its incipient forms, the study provides strong evidence in a different spatial and cultural context of a positive relationship between local resource users leadership, on the one hand and, on the other hand, the conservation and sustainable development of ecotourism within protected areas (Evans et al, 2015; Manolis et al, 2009), thus corroborating the findings of other studies.

In the following, we briefly review literature on guerilla gardening, co-management of natural resource, and user-leadership within the context of the adaptive co-management literature. Afterwards, we identify and describe the phases of land use evolution of MWGs, illustrating three of these phases showing incipient forms of co-management with specific case studies. We then analyze the data and discuss the findings. Finally, some recommendations are provided to promote local community involvement in natural resource co-management.

\section{Guerilla gardening: meaning and motivations}

Guerilla gardening, defined as "the illicit cultivation of someone else's land" (Reynolds, 2008: 16), may have existed long before it attracted the attention of scholars in the 1970s. Since then, the interest in the topic has bourgeoned in academic literature, social media, web-based forum, and news media (Adams, Hardman \&

\footnotetext{
${ }^{1}$ In the initial preparatory documents for the Country Parks Bill, 'residing and squatting' were included in the long list of activities subject to control of use, but this was eventually subsumed under "any other similar activities" in the final legislation at the request of the Governor of trimming down the list (Secretary for Environment, 1975: HKRS684-3-55-26).
} 
Larkham, 2015). The term 'guerilla gardening' may have possibly been first coined in 1973 by a grassroots movement in New York City called the Green Guerrillas whose primary aim was to cultivate and beautify derelict spaces (Adams, Scott \& Larkham, 2013). Some of the basic features of guerilla gardening are individuals or groups involved are volunteers; they do so without permission; often they target public and private spaces of neglect; and, they transform the environment through the planting of flora” (Flores 2006 in Adams \& Hardman, 2014: 1103-04). More recently, guerilla gardening has also been called urban activist gardening, particularly when "it involves the temporary transformation of vacant construction sites - such as wasteland, abandoned car parks and vacant rooftops - into urban farmland and green meeting places” (Graf, 2014: 452). The rise of the Do-It-Yourself (DIY) urbanism movement promoting a variety of self-help urban beautification efforts has received its impetus from guerilla gardening (Finn, 2014). As a form of DIY urbanism or guerilla urbanism, activists carry out "urban planning interventions commonly characterized as small scale, functional, temporary, creative, and place specific" (Heim LaFrombois, 2015: 1). Although guerilla gardening and other forms of DIY urbanism take place outside formal urban planning structures and systems, in some places like Amsterdam, the Netherlands it has been adopted as an experimental tool in small-scale improvements and temporary use of urban space by the local government, with the potential of becoming a formalized urban planning strategy and receiving longer-term investment. Fabian and Samson (2016: 166) list other terms found in literature to refer to "the various forms of creative, localized attributions and alterations of urban environments" It is important to note however the focus on urban spaces in these concepts.

Guerilla gardeners perceive neglected and underused areas as loose space lying somewhere between individual private property and the 'commons' (Blomley, 2004), and they cultivate these spaces for social and symbolic functions (Sbicca, 2014). The social function emphasizes gardening as an enjoyment for the community and as an opportunity for social interaction, whereas the symbolic function tends to focus on the transgressive nature of guerilla gardening, that is, as a means to show resistance against mainstream culture or hegemonic planning (Adams \& Hardman, 2014). Some of the social purposes of guerilla gardening are: improving the landscape and increasing biodiversity, food, health, and business (Reynolds, 2008; Adams, Scott \& Larkham, 2013). Lyons (2014) stresses the role of guerilla gardening as one of the means to better achieve food security in the midst of poverty and hunger. Another social function of guerilla gardening is for community use by providing education (e.g. botany, benefits of community gardening), recreation (e.g. picnic, barbecue, gardening), and socializing with friends and newcomers or passersby. In addition, guerilla gardening provides opportunities to achieve environmental justice through direct action, rather than just complaining to officials or reacting to what happens (Shepard, 2014). Ralston (2012) suggests the idea of school gardening as a gateway to gardening activism. 
The symbolic value of guerilla gardening lies in its capacity is to express a message, whether to demonstrate that something widely thought to be impossible as possible or as a reminder to the community about an important event that happened in a place or to transmit hope or optimism or to show resistance against government planning policy such as redevelopment. Academic literature often portrays guerilla gardening as expression of resistance that opposes government's rhetoric and rejects neoliberal agendas (Adams, 2015). Guerilla gardeners perceive planning as an uncertain and time-consuming process (Adams, Hardman \& Larkham, 2015), and oppose government control and ordering of space, claiming the right to participate in shaping landscapes by direct action (Adams \& Hardman, 2014). Cilliers \& Timmermans (2014: 422) argue that guerilla gardening can be considered as a tool "to enhance community participation within the place-making process," and participation can be fostered by enhancing their connection to the place through ownership. Crane et al (2013: 71) consider guerrilla gardening as "a powerful pathway towards producing engaging and sustainable communities." Guerilla gardening is an innovative initiative of grassroots individuals and groups for social interaction and networking, for knowledge exchange, and for building and strengthening social capital and cohesion. In this sense, guerilla gardening can be seen as a non-conventional means by which the local community can become partners of the government in achieving social goals and benefits.

However, Adams, Hardman \& Larkham (2015) point out some of the criticisms against guerilla gardening, contradicting or weakening some of its social and symbolic functions above. These criticisms relate community, property rights, and environmental issues. Some guerilla gardeners may tend to be a closed group and fail to interact with the people and environment around the space they cultivate. This can make the wider community feel excluded from the garden. Private individuals feel victims of injustice when guerilla gardeners colonize their property which they fence off barring access to their own property. The short-term sporadic guerilla gardening, which has become quite common in recent years, has the disadvantage of the piece of land reverting back to its previous state of neglect.

Despite assertions of the global phenomenon of guerilla gardening, literature on the subject in the Asian context is still wanting. Reynolds (2008) identifies specific individual guerilla gardeners in Singapore and Japan. Notwithstanding claims that "urban activist gardening is practiced in almost all cities in the world" (Graf, 2014: 452), guerilla gardening literature has hitherto focused on American, European, and Australian contexts. A Scholar Google search for studies on guerilla gardening reveals that studies in the Asian context has largely been neglected.

\section{Natural resource co-management in protected areas}

Co-management is a management approach referring to the “...sharing of power and 
responsibility between government and local resource users, involving some kind of formal arrangement” (Premauer \& Berkes, 2015). Apart from power sharing, co-management also involves institution building, social capital, trust, knowledge, social learning (Blore et al, 2013), and legitimacy (Hoffman, 2009). Co-management is heralded as a solution to the inadequacies of the command-and-control approach to natural resource management, particularly those within protected areas whether terrestrial such as national parks and forest reserves (for example, Mehring et al, 2011) or marine such as fisheries (for example, Pinkerton, 1989). Since the 1970s, there has been a governance shift from rational comprehensive approach with little community participation to a participatory planning process (Getzner et al, 2014) underpinned by the norms and values of equity, efficiency, sustainability, and power distribution (Wever et al, 2012; Brewer and Moon, 2015). The participatory nature of co-management is understood as a strategy to improve the management of protected areas, efficiency, effectiveness, and equity, and thus lead to sustainable development of national parks (Brewer \& Moon, 2015). It is an innovative solution for dealing with the issue of conservation threatened by unsustainable natural resources exploitation (Granek et al, 2005). It has the potential to create a win-win solution for the government and indigenous communities (Almudi \& Berkes, 2010). The term co-management can be found in the earliest documented examples of resource partnership agreements involving the fisheries in Norway and Japan. However, the modern notion of co-management in which the rights of users includes both the operational ones (right to access, use, and exploit) as well as the collective action rights (right to participate in the process of planning and decision-making) emerged in the 1970s. This contemporary concept is also referred to as 'concurrent management' (Plummer \& Armitage, 2007).

The co-management approach has been adopted for the protected area management in many places around the world. Kakadu National Park in Australia is a pioneer of protected area joint management (Haynes, 2013). UK national parks were one of the first to implement co-management, emphasizing user engagement, local community empowerment, and sustainability (for example, Clark \& Clarke, 2011). The governments in various African countries implement partnership arrangements to manage their national parks such as Kruger National Park in South Africa (Cundill et al, 2013), Tsavo East and Tsavo West National Parks in Kenya (Mburu \& Berner, 2007), and W Regional Park straddling the borders of Niger, Burkina Faso, and Benin (Torquebiau \& Taylor, 2009). Examples of the use of joint management framework are also found in protected areas in Greece (Vokou et al, 2014), Makuira National Park in Spain (Premauer \& Berkes, 2015), and forest reserves in Vietnam (KimDung et al, 2013).

There are various governmental and non-governmental stakeholders in natural resource, and it is widely accepted that the effective participation of these actors in the management of national parks can achieve successful conservation and sustainability (Vokou et al, 2014). Joint management involves managing not just natural resources 
but also resource users (Arceo et al, 2013), among whom are recreationalists whose recreational activities can be affected by rules regarding protected areas which they may resent (Kirkpatrick, 2001). Decentralization in natural resource management empowers resource users, fosters local user participation and promotes upward accountability (Nagendra, Karmacharya \& Karna, 2005). Sharing of power means conferring rights, not just privileges, to local users and treating them as partners rather than subjects in resource management (Namara, 2006). Nevertheless, the government, through its commitment and support for local users' activities and its capacity to withstand external difficulties, plays an important role in enabling co-management (Vikou et al, 2014). It is important to avoid situations wherein natural resource management is purely by government without participation or where government support is completely absent. While co-management is typically between the state and local resource users (Ross et al, 2009), NGOs can also play an important role, particularly as bridging organizations to facilitate communication and conflict resolutions (Borrini-Feyerabend, Kothari \& Oviedo, 2004), overcome co-management problems (Almudi \& Berkes, 2010), or fill in a knowledge gap (Horigue et al, 2012).

Co-management can also be understood as a relationship between involved parties based on certain property rights (Haynes, 2013), specifically with respect to the use of natural resource. Property rights are social rules that define the rights and duties of stakeholders, and thus their interrelationship, with respect to property (Alchian \& Demsetz, 1973). Property rights consist of a bundle of rights which have been classified into the rights to use the property, to derive income from the property and to alienate the property (Alchian \& Demsetz, 1973) or the rights of access, withdrawal, exclusion, management, and alienation (Schlager \& Ostrom, 1992). The establishment of protected areas in some places has resulted in the disenfranchisement, often uncompensated, of local communities from the land or waters they depend on for their livelihood (for example, Maclean et al, 2013). Co-management is used as a means to address land claims and such social injustices. However, partnership arrangements alone do not necessarily constitute successful land claims, as shown in the experiences in various countries such as South Africa (Cundill et al, 2013) and Vietnam (KimDung et al, 2013). If co-management does not resolve concerns about property rights, it undermines social justice and threatens conservation (Kepe, 2008). Effective co-management needs to incorporate the legal protection of indigenous people's rights. Thus, Bruckmeier (2005) argue that the allocation of ownership rights is one of the preconditions for sustainability of co-management systems.

Co-management is a strategy which combines both standardized regime of aims and processes, on the one hand, and self-organization on the other hand (Berkes, 2004). Effective co-management stresses the importance of both vertical and horizontal communications. The lack of vertical communication contributes to conflicts due to the misalignment between the government's conservation goals and resource users' expectations (Hoffman, 2009). Better horizontal communication within the 
community builds co-management capacity (Ross et al, 2009). Co-management has the capacity to resolve conflicts arising from decisions made by officials that are not discussed with local users or from some traditional and livelihood practices of indigenous people that are incompatible to conservation (Pramauer \& Berkes, 2015).

Co-management contributes to trust building, increasing local resource users' acceptance and willingness to enforce regulations and collaborate in implementing programmes and in working towards achieving objectives. When local communities are provided adequate involvement in the joint management of natural resources, they show greater level of compliance with protected area policies (Andrade \& Rhodes, 2012). Co-management increases local resource users' ability for self-organization (Getzner et al, 2014), self-regulation, compliance, and cooperation with park regulations (Hoffman, 2009). Some examples attesting to this are the joint management of marine resources in the Philippines (Horigue et al, 2012) and of coastal ecosystems in the Caribbean (Smith, 2012). Wever et al (2012: 70) argue that "the active involvement of concerned ecosystem users can increase the legitimacy of public authority and the local predisposition to follow rules.” Co-management also has the advantage of allowing the state to tap into local knowledge which is recognized as important for the effectiveness of conservation and sustainability of protected areas (Vokou et al, 2014), particularly when dealing with complex and pressing natural resource management problems (Blore et al, 2013). Co-management emphasizes knowledge sharing which involves, among others, filling in knowledge gaps among partners and alerting other actors about issues that need close attention and monitoring (Berkes, 2009). Local resource users are an important source of ecological knowledge, particularly of information in remote areas, far from park and research centers, which inform problem-solving and decision making (Gerhardinger, Godoy \& Jones, 2009).

More recently, co-management has been associated with adaptive management (KimDung et al, 2013). While co-management emphasizes sharing of knowledge, a defining feature of adaptive co-management is social learning as a means to deal with environmental uncertainties (Berkes, 2009). Social learning involves not only sharing of knowledge but also sustained interactions between stakeholders and on-going deliberation in a trusting environment (Cundill \& Rodela, 2012). The adaptive management literature provides a rich treatment of leadership among stakeholder groups as an important factor to obtain positive outcomes in collaborative efforts in conservation and sustainable development.

\section{User leadership in the adaptive management context}

There is a general recognition of the significance of mutually supportive leadership, between user groups and the government, in natural resource partnership management, 
and its absence is associated with conflicts and negative environmental outcomes (Evans et al, 2015; Manolis et al, 2009). Leadership of the participating parties is essential for the success and effectiveness of collaborative efforts management (Olsson, Folke \& Berkes, 2004), particularly because natural resource management involves building trust, managing conflict, building networks, and transferring knowledge (Emerson \& Gerlak, 2014). User leadership, in particular, contributes to enhancing the adaptability and resilience of a specific resource system (Maclean et al, 2014). The adaptive management and governance literature highlights specific features of user leadership, such as the capacity of individuals and organizations for self-organization (Getzner et al, 2014), for establishing and facilitating horizontal and vertical linkages (Olsson et al, 2006), for building local knowledge networks (Evans, 2010), for providing energy, understanding of community processes and needs, and for resolving conflicts and promoting awareness (Sutton \& Rudd, 2014). The capacity for self-organization emphasizes that user leadership can make co-management work and facilitate the participation of local communities in ways that contribute to protected area conservation and sustainable development efforts, and to providing what the state may be lacking in terms of establishing links with other resource users (Olsson et al, 2006). Local resource users are knowledge holders who with their long interaction with the resource system and connection with past generations of knowledge holders play an important role in natural resource governance processes (Evans, 2010). Informed by local knowledge of the ecosystem, community leaders can advocate and contribute to policy change that can improve resilience of social-ecological systems management (Clarvis \& Engle, 2015). Local leaders can mobilize volunteers and facilitate effective community networks which help to encourage users groups and individuals to work together, to create shared vision, and to help improve policies or programs for sustainable ecosystems (Maclean et al, 2014). However, resource user leadership can be constrained by the lack of leadership continuity (Sutton \& Rudd, 2014), inadequate financial means, and lack of respect from other park users (Akamani et al, 2015). Sutton and Rudd (2014) emphasize leadership by a user group, rather than just an individual, to provide continuity of local community leadership succession and project. Dietz, Ostrom and Stern (2003) stress the importance of combining financial incentives to collaborative partnerships. In situations where other park users ignore reminders by local community leaders about park regulations, the latter can still continue being catalysts and promoters of conservation by bringing illegal behaviors of others to the attention of officials for better rule enforcement (Ruiz-Mallén, 2015).

\section{Methodology}

The article presents three case studies. Site visits were conducted to more than twenty MWGs, those indicated in Agriculture, Fisheries and Conservation Department (AFCD) official maps, as well as those serendipitously discovered during hikes between gardens, from April 2015 to April 2016 (See Table 1). Most of the gardens 
visited were originally built by morning walkers and a few by the government. The latter is excluded from the study. Also excluded from the study are MWGs, built either by morning walkers or government, situated outside protected areas. The former is usually managed and operated by a community of morning walkers as a rain shelter under a license renewable annually subject to payment of a minimal fee to the Lands Department. The latter is usually managed by a government agency under the Home Affairs Department.

\section{Table 1: Number of MWGs visited}

\begin{tabular}{|l|c|}
\hline Country park (Area) & Number of MWGs visited \\
\hline Lung Fu Shan (Hong Kong Island) & 4 \\
\hline Aberdeen (Hong Kong Island) & 5 \\
\hline Tai Tam, Quarry Bay Extension (Hong Kong Island) & 6 \\
\hline Kam Shan (Kowloon and New Territories) & 8 \\
\hline Lion Rock (Kowloon and New Territories) & 7 \\
\hline \multicolumn{2}{r}{ Total } \\
\hline
\end{tabular}

Semi-structured interviews were conducted with a total of forty-five morning walkers (See Table 2). These are morning walkers who either belong to the original or early group of guerilla gardeners or came later. They cultivate, use, and maintain these gardens. The oral histories they provided were particularly useful, because on-line data about the gardens are scant. Some of the questions asked relate to the history of the garden (for example, who 'founded' the site and when; how many; their basic profiles; why was the site chosen; original facilities provided in the garden), activities carried out in the garden, and how they maintain and manage the garden. We also asked them about their relationship with park officials and how they think it could be improved.

Table 2: Number of morning walkers interviewed

\begin{tabular}{|c|c|}
\hline MWG & $\begin{array}{l}\text { Number of morning walkers interviewed } \\
\text { (women : men) }\end{array}$ \\
\hline Fool's Paradise & $9(6: 3)$ \\
\hline Friendship Terrace & $4(1: 3)$ \\
\hline Chinese Herbal Garden & $4(1: 3)$ \\
\hline Other gardens & $28(16: 12)$ \\
\hline Total & $45(24: 21)$ \\
\hline
\end{tabular}

\section{The five phases of evolution of Morning Walkers' Gardens}

The 'Morning Walkers' Gardens' (See Figure 1) provided in Country Parks in Hong Kong (Wong, 1997) have an interesting origin. The 1960s and 1970s saw the 
proliferation of 'private' gardens in the mountainous countryside, which was Crown land, 'founded' and cultivated by different communities of morning walkers. While these gardens remain open access, their 'discoverers' habitually used these areas for their recreational activities. Most of these gardens have fixed structures built by morning walkers. They are illegal but tolerated by the government. Many are now part of protected areas; others are typically situated at the fringe of country parks, and are granted license to operate as rain shelters. There are also government-built MWGs in protected areas. The study focuses on gardens built by morning walkers and part of protected areas, because these manifest some form of partnership arrangement.

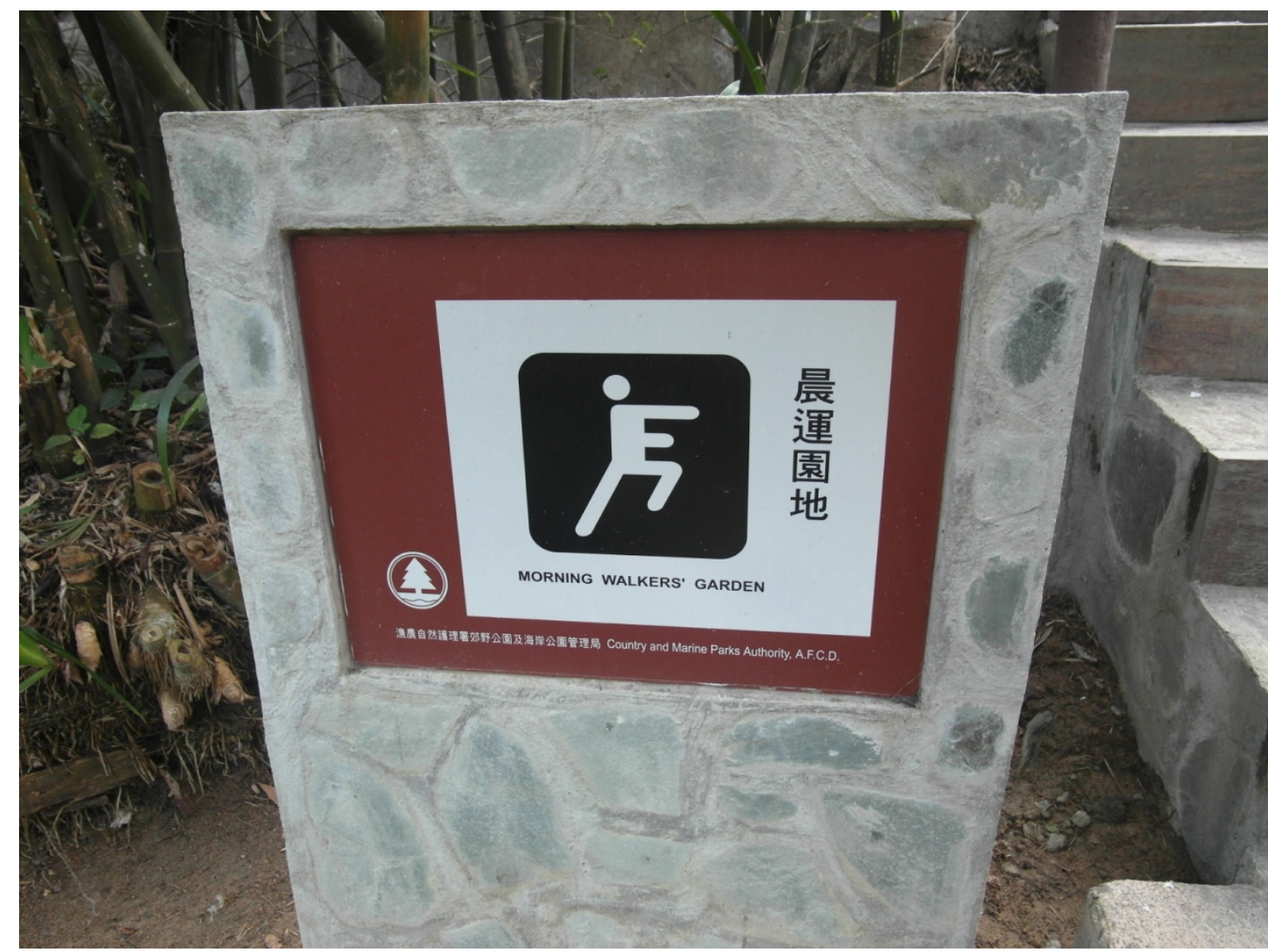

Figure 1: Typical MWG signage in country parks

The estimated sizes of MWGs range from 50 to 3,500 square meters, some with fixed recreational facilities and others without. These gardens were given names that reflect their use and nature; some names can even sound hilarious. Many have been demolished since the introduction of the country park system in 1976. Remnants of abandoned and demolished private gardens can easily be found near government-built rain shelters (or pavilions) or wartime heritage structures. The three guerilla gardens presented in in this study were built by morning walkers more than three decades ago. At that time, they were in their thirties or forties. The proportion between men and women was more or less equal (See Hung (2015a) for more details about the basic profile of morning walkers). Their primary purpose was to build a 'base' for their recreational activities in the mountains. We have identified five distinct phases in the evolution of the land status of these MWGs: 1) tolerated; 2) registered; 3) recognized; 
4) zoned; and, 5) enhanced.

\subsection{Stage of toleration}

Before country parks were introduced, the government adopted an approach of toleration towards countryside gardens built by morning walkers, provided these did not pose immediate administrative problems. A similar policy of toleration was adopted by the government towards those urban squatter settlements that were not being considered for imminent development (Smart, 2001). Besides, in the early years, though small in size, the location, number of these gardens, and the rate at which they proliferated meant that their control and eradication presented a daunting task for the government.

\subsection{Stage of registration}

Upon designation of country parks, existing private gardens were required to be registered for control. These were not demolished, perhaps in consideration to the length of time they have been around. But they were required to be maintained in good condition, especially those with fixed facilities, to avoid causing harm to the environment or the health and safety of other country park visitors. Where boiling tea was also allowed, making fire had to done in a designated place in the garden to avoid fire hazard. Any development is frozen, that is, any extension of existing facilities or addition of new facilities were prohibited and would be demolished (Golger, 1972). Country park wardens regularly conduct site visits to monitor compliance with conditions. Officials destroyed built structures in private gardens that were eventually abandoned by their morning walkers. The other standard prohibitions are tree cutting, excavation, and the use open containers to collect rain water to avoid turning them into breeding ground for mosquitoes which can cause the spread of dengue fever. Unregistered private gardens were demolished. The government has implemented a tight control over attempts to build new private gardens, with country park rangers making regular and frequent patrols. Some registered gardens have never gone beyond the stage of registration. ${ }^{2}$ These gardens do not have any particular names. These gardens are very simple, with no fixed facilities except a flat exercise area. Some signs of past cultivation can be seen but remnants show that gardening has long been discontinued, most likely due to the difficulty in protecting the plants or flowers they planted.

\subsection{Stage of recognition}

After the implementation of the country park system and the registration of private gardens, the government began to recognize some of these gardens as MWGs. Recognition meant that officially produced AFCD maps indicate the approximate

\footnotetext{
${ }^{2}$ It is possible that in other country parks not visited by the author there are also other gardens that have not gone beyond the registration phase.
} 
locations of these MWGs. Though recognized, there is no guarantee that they would not be demolished in future.

\subsection{Stage of zoning}

In addition to having their locations identified in official maps, zoned MWGs are all clearly signposted which indicate an official designation as MWGs. Another important feature of zoned MWGs is that there is government investment on the construction and maintenance of facilities. Funding for building a rain shelter has come from either the AFCD or Home Affairs or the relevant District Councils ${ }^{3}$. In some cases, several government agencies are involved in funding facilities. While morning walker groups are expected to maintain their respective MWGs, the government covers costs of repairs to facilities, as well as maintaining slopes and providing rubbish bins. In some cases, AFCD has produced maps clearly showing their boundaries; in other cases, a promotional map was produced in which these MWGs are highlighted as one of the varied recreational facilities provided in country parks. These maps are posted near these gardens where they can be easily seen by other visitors. Zoning meant that these gardens have been clearly incorporated into country parks land use planning.

\subsection{Stage of enhancement}

Enhanced MWGs involves transformation by changing or adding a new use that enhances the value of the garden. The new or additional use of the garden has involved collaboration between user groups, government, and NGOs. Activities carried out in transformed MWGs are more diversified than registered or recognized MWGs.

Table 1: Number of gardens built by morning walkers visited and their locations

\begin{tabular}{|l|c|c|c|c|}
\hline Country Park & Registered & Recognized & Zoned & Enhanced \\
\hline Aberdeen & & & 5 & \\
\hline $\begin{array}{l}\text { Tai Tam (Quarry Bay } \\
\text { Extension) }\end{array}$ & & & 5 & \\
\hline Lung Fu Shan & & & 1 & 1 \\
\hline Kam Shan & Several & 5 & & \\
\hline Lion Rock & & & 2 & \\
\hline
\end{tabular}

\footnotetext{
${ }^{3}$ District councils in Hong Kong are organizations of district administration whose function is mainly advisory with some executive powers limited to carrying out environmental improvements, recreational and cultural activities, and community activities in areas within the respective districts.
} 


\section{Three case studies}

Three cases (See Figures 2 and 3) are presented here to illustrate these three MWG types that manifest incipient forms of co-management of natural resources in protected areas and local user leadership, namely, recognized, zoned, and enhanced.

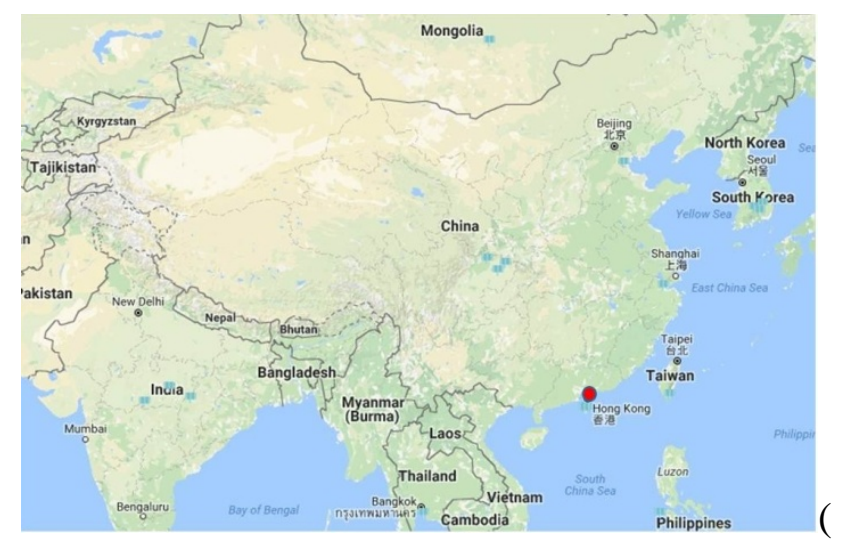

Figure 2: Location of Hong Kong (Source: Google Map)

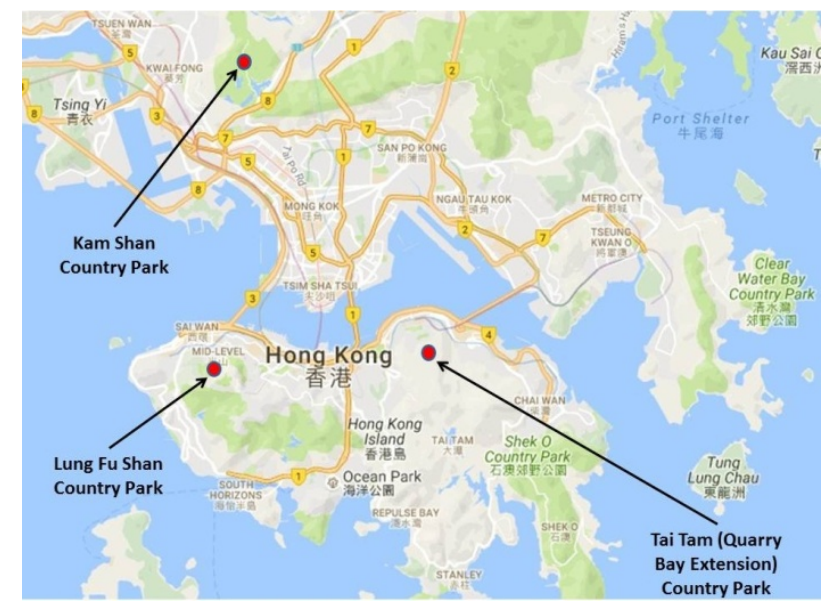

Figure 3: Locations of Kam Shan, Tai Tam (Quarry Bay Extension), and Lung Fu Shan Country Parks where the three cases are located (Source: Google Map) 
Case 1: Fool's Paradise (Recognized MWG)

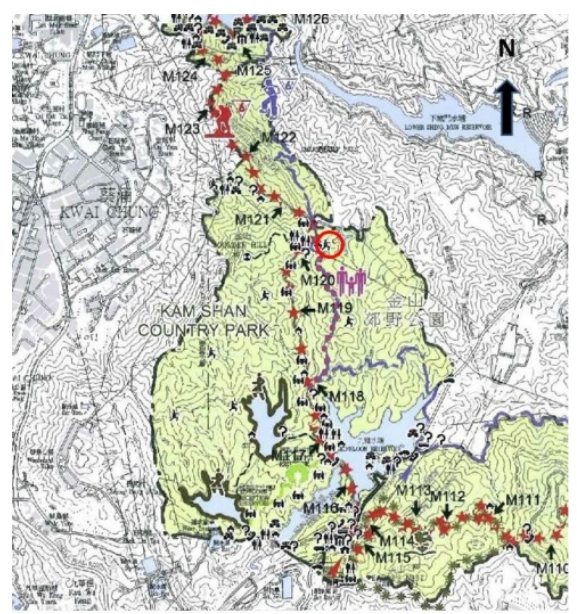

Figure 4: Approximate location (encircled) of Fool's Paradise in Kam Shan Country Park (The map reproduced with the permission of the Director of Lands. (C) The Government of the Hong Kong SAR. License No. 93/2016.)

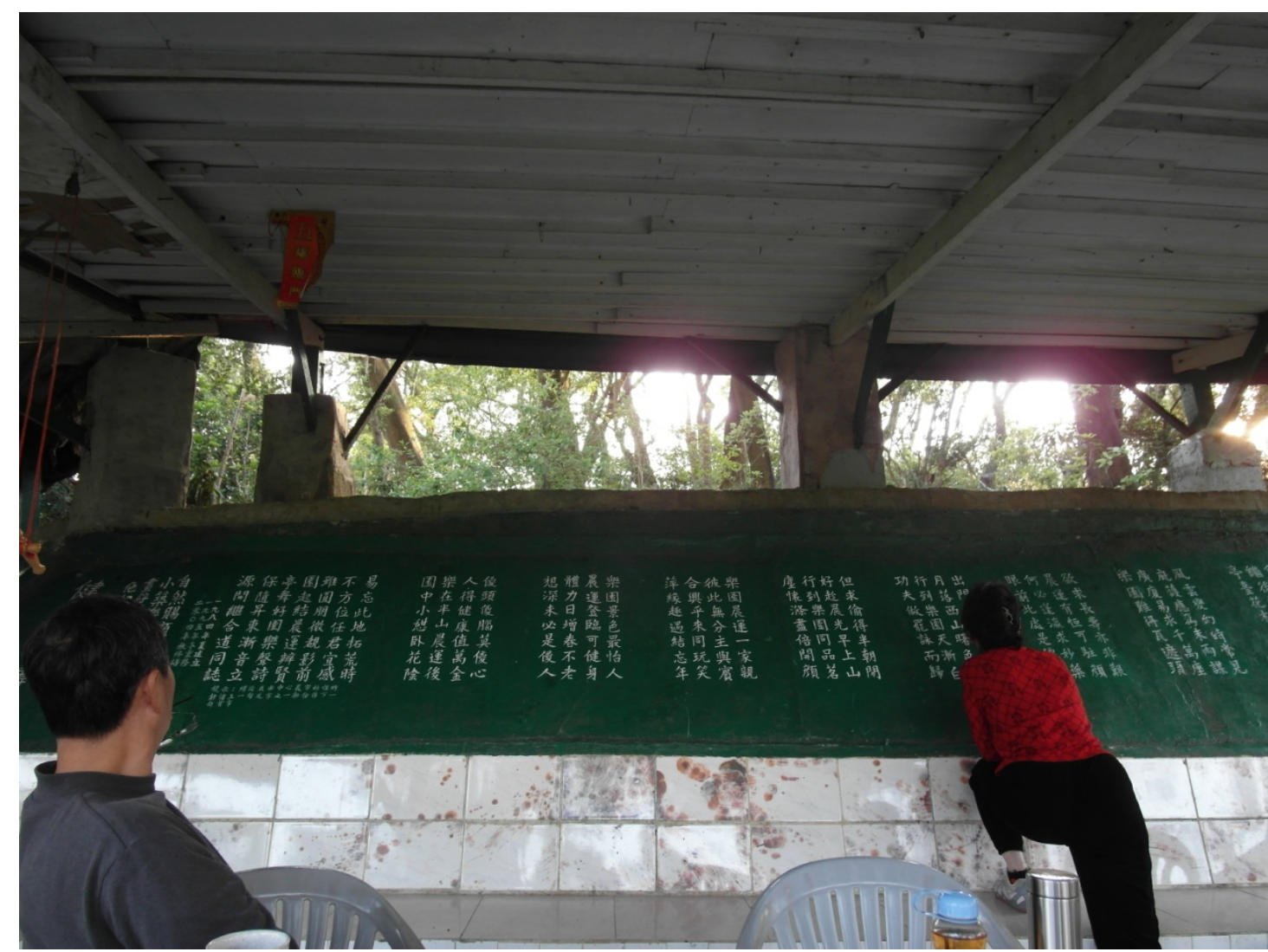

Figure 5: A morning walker touching up the Chinese poems written in artistic inscriptions on a wall under a rain shelter (Photo taken by the author) 
Fool's Paradise (See Figures 4 and 5) was built in the 1970s by a group of morning walkers who were at that time aged 30 to 40 years. At present, about six to seven users from the original group continue to come every morning, along with other junior morning walkers. Apart from complying with park rules and the conditions which came with the permission to keep and use the garden, they also maintain the garden on their own. They have a strong bond of friendship among themselves and a strong sense of belonging to the garden, contributing money and time for the upkeep of the garden. They have put up signs reminding other users to keep the garden clean. The garden is a favourite stopover of various hiking groups. They even offer them tea to drink. They are hoping that the government would eventually install some outdoor fitness equipment in their garden. One of the 'fools' said,

"We are not really interested in exclusive property rights over the garden. This is a country park, and we cannot fence off the garden; it has to remain open to other park users. But what we want the government to do is to install a shoulder rotator ${ }^{4}$ (See Figure 6). We are not allowed to add anything to existing facilities. So, we are hoping the government could be the one to do it...We have tried to repair the slope in front of our garden that was getting eroded, but the government did not allow us to do it. Instead, they were the ones who repaired it.” (Interview with Mr. W)

\footnotetext{
${ }^{4}$ We have observed that the morning walkers have only a makeshift exercise equipment consisting of a small pulley and rope hanging down from the roof of their rain shelter which by pulling the rope down can achieve the up and down movement of the arms.
} 


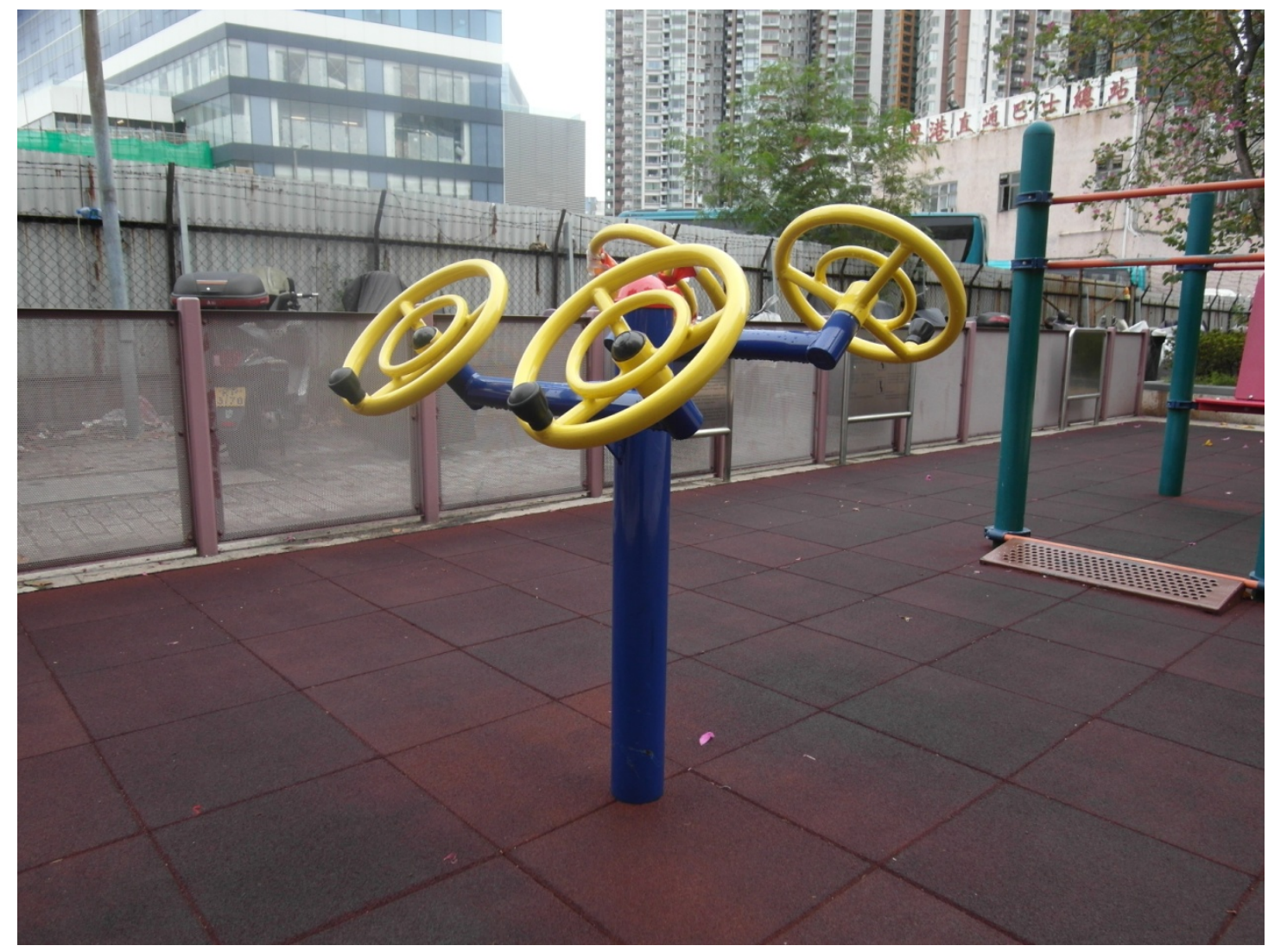

Figure 6: A typical shoulder rotator (Photo taken by the author)

Case 2: Friendship Terrace (Zoned MWG)

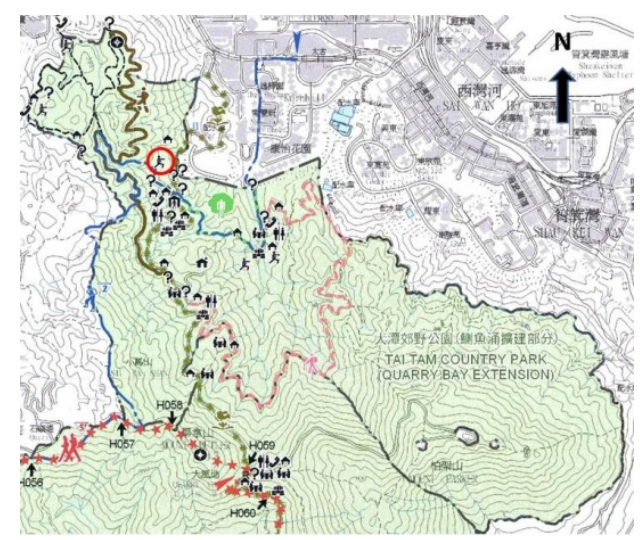

Figure 7: Approximate location (encircled) of Friendship Terrace in Tai Tam Country Park, Quarry Bay Extension (The map reproduced with the permission of the Director of Lands. (c) The Government of the Hong Kong SAR. License No. 93/2016.) 


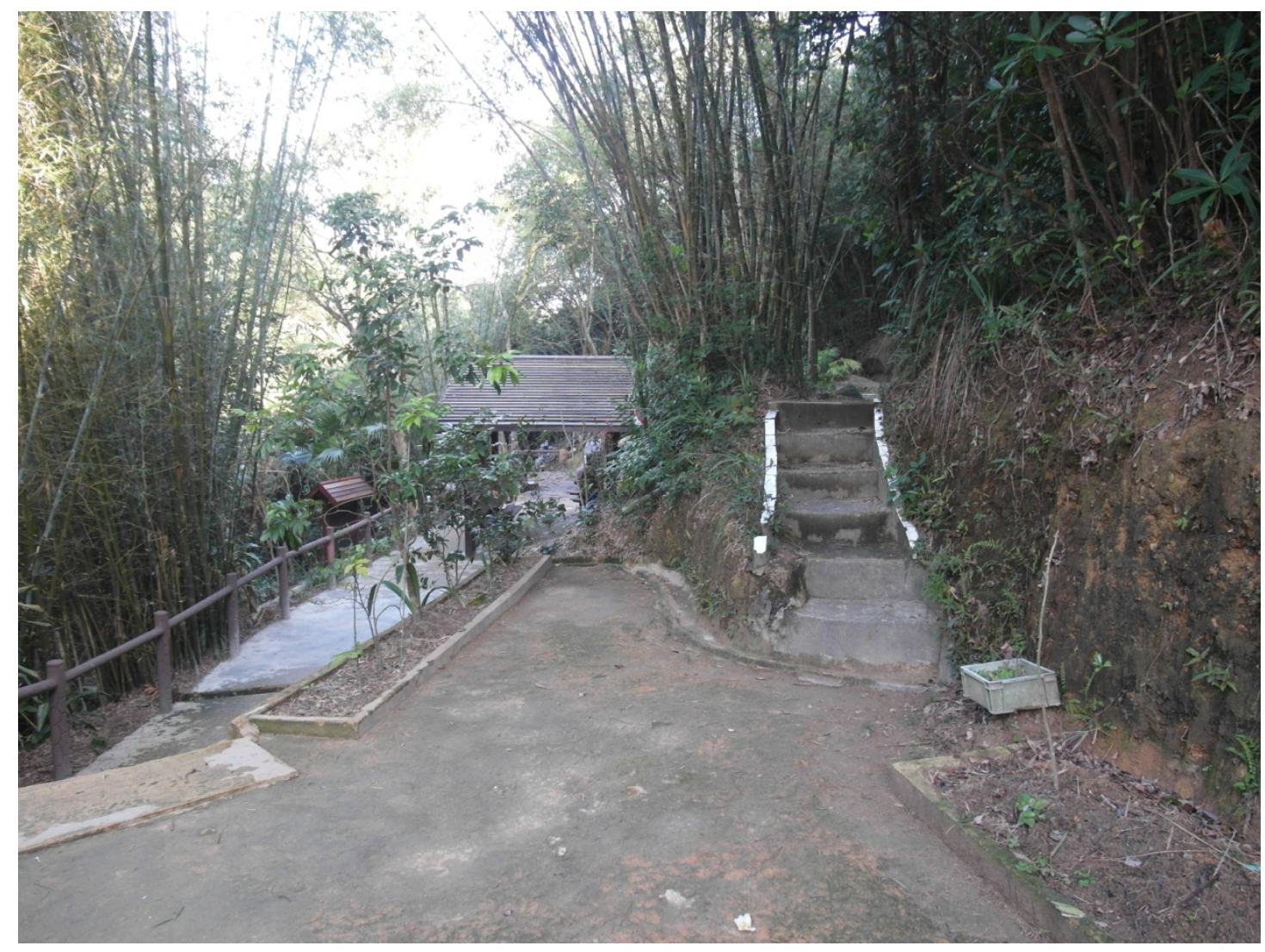

Figure 8: Friendship Terrace taken from the garden and exercise area; behind at the lower level is where morning walkers gather to drink tea and chit chat (photo taken by the author)

The morning walkers of Friendship Terrace (See Figures 7 and 8) have a good relationship with the Eastern District Council, particularly with a district councilor who happens to be an avid morning walker in the country park. He has helped them to apply to the AFCD for a rain shelter replacing the already dilapidated one that was built by the original morning walkers. The government has also built for them a concrete stove, a small concrete storage, and a few wooden benches. The boundaries of the garden are well defined in a map produced by the AFCD and posted on an information board in front of the garden. Park officers have asked them to preserve the rock on which the original morning walkers have inscribed the name of the garden for its artistic value. The regular maintenance costs of the garden's facilities are covered by the AFCD. The garden is very clean, and they even grow some orchids. But one of the morning walkers, who is in his 60s, said,

"I hope the government improves the mountain trail to the garden to make it easier for old morning walkers like me to come here. The trail is so uneven. I think they should do something about it.” (Interview with Mr. H) 


\section{Case 3: Lung Fu Shan Chinese Herbal Garden (Enhanced MWG)}

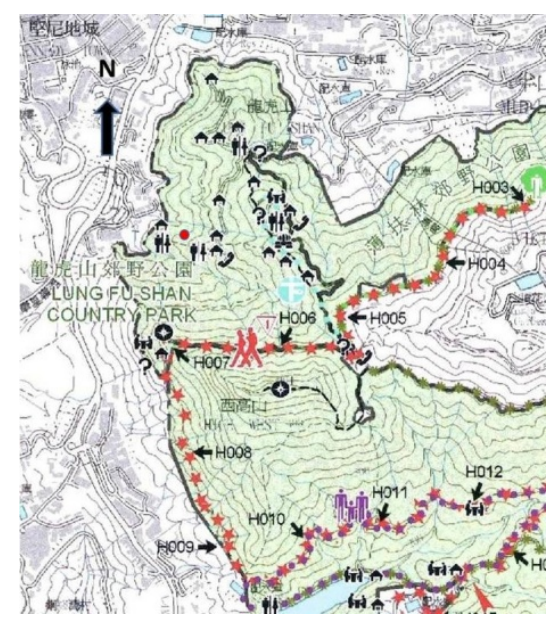

Figure 9: Approximate location (dotted) of Chinese Herbal Garden in Lung Fu Shan Country Park (The map reproduced with the permission of the Director of Lands. (C) The Government of the Hong Kong SAR. License No. 93/2016.)

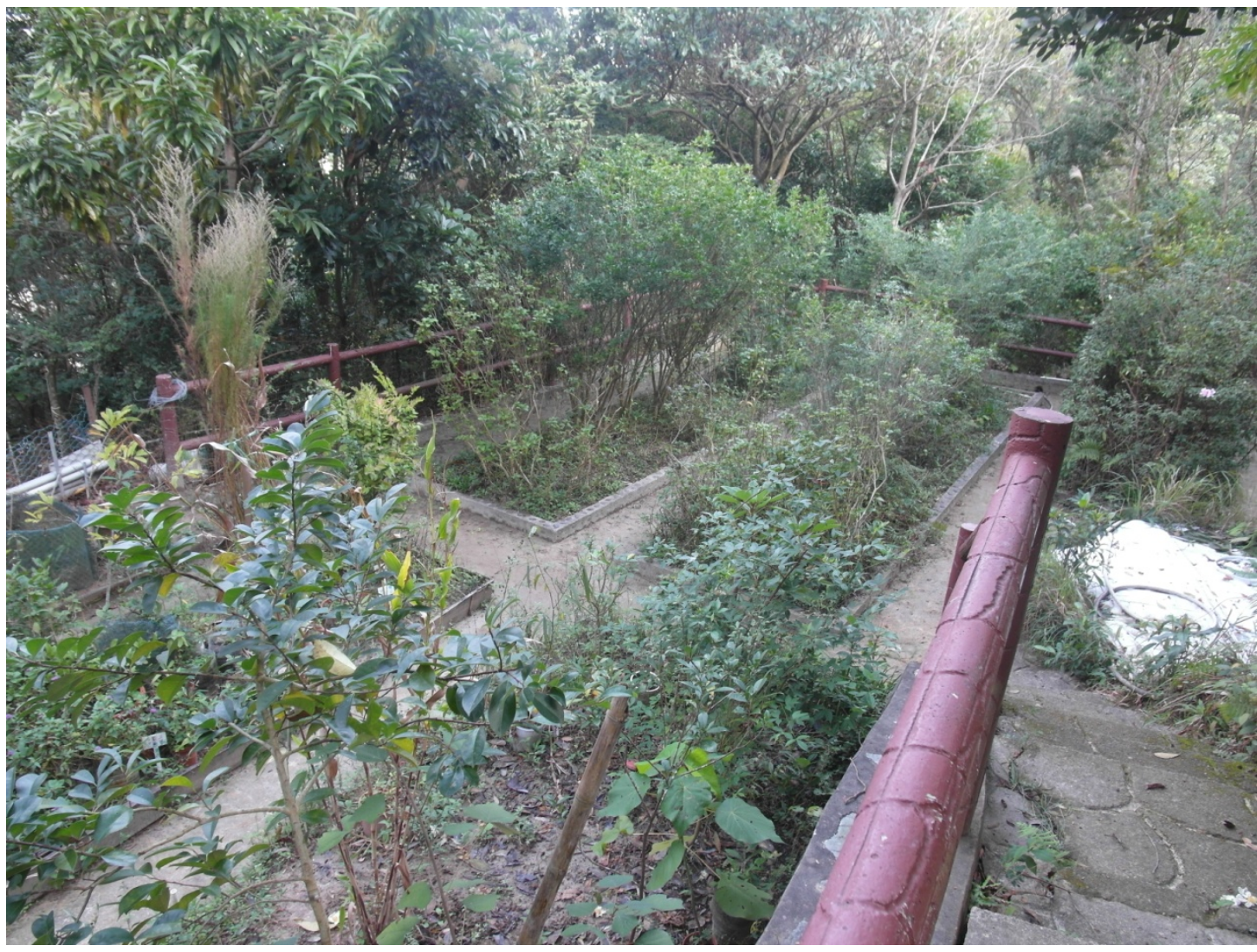

Figure 10: Chinese Herbal Garden (photo taken by the author)

Three to four morning walkers began to cultivate the garden to grow vegetables mainly for their own consumption, and to use it for their recreational activities. When 
the government found out, the garden was allowed to stay but it was not recognized until after the designation of the park in 1998 and the establishment of the Chinese Herbal Garden (See Figures 9 and 10) in 1999, the latter under a semi-formal co-management arrangement between the government and the Lung Fu Shan Morning Walkers Association, a not-for-profit NGO, established by the morning walkers who "founded" the garden and other morning walkers. The Association's chairperson and committee members serve for a term of two years. The chairperson who is elected has been the same one (hereinafter CSK), affectionately called 'uncle' by park users. CSK was very happy to learn about the designation of the country park. As a long time park user, he had seen the deterioration of the natural environment and the chaos caused by illegal structures and activities. He took us to a hillside where an altar to the Chinese gods built by a group of morning walkers used to stand. Park users were asked to pay two dollars if they wanted to walk along a footpath in front of the altar. It was his idea to convert the vegetable garden into a Chinese herbal garden for educational purposes. Chinese herbal medicine is a cultural heritage in Hong Kong and China. But it also had a special meaning for him due to an unforgettable childhood experience which made him wonder at its medicinal powers. ${ }^{5}$

The establishment of the Chinese Herbal Garden ${ }^{6}$ was a joint decision by the government, Central and Western District Council, and the Association. It was officially inaugurated in 2002. Under the partnership arrangement, the Association's responsibilities are to carry out the day-to-day management of the garden and to co-organize educational activities. The have received financial assistance from the government and the district council for the garden's maintenance cost and educational initiatives. They plan to expand the now five hundred types of Chinese herbs to eight hundred or one thousand. In 2015, the Association has about three to four hundred 'honorary' members who are professionals and community leaders and are a source of knowledge, expertise, and contacts, and needed assistance for training courses.

CSK showed enthusiasm for the partnership project, ability to establish networks with scholars, university professors, and other community leaders, and care for the protection of the park and the concern for the safety and health of park users. He plays the role of a convenor, calling for meetings with representatives of the government and the district council to communicate suggestions, concerns and needs of park users on how to improve conservation and safety in the park.

"We have been collaborating with the government to improve safety of park users...We also promote the park for ecotourism, integrating nature trail, heritage trail, and Chinese herbal medicine...I am proud to say that Lung Fu Shan Country Park is the only country park in Hong Kong

\footnotetext{
${ }^{5}$ In an interview he said, "Back in my village in China where I grew up as a child, the family had a cow on which we depend for our livelihood. One day the cow fell ill and was at risk of dying, but it managed to avoid death when my father fed it a particular kind of Chinese herb. The cow survived and because of that the family managed to survive during those hard years."

${ }^{6}$ The garden is also known by its official name of "Planting Site No. 1."
} 
which integrates these three elements...We would also post announcements about a lost and found items on information boards, so that owners could contact us to recover their belongings." (Interview with CSK)

The Association has submitted a number of suggestions to the government pending replies and is planning to improve their co-management capacity. They have requested the provision of an area within the park which can be easily accessed by a small ambulance car for emergencies. They have also asked for increasing the height of the fences around the Chinese Herbal Garden to better protect the Chinese herbs from wild boars as well as casual hikers who tend to ignore signs not to pick herbs. They have submitted an application to be registered as charity to enable them to receive donations and to raise funds to carry out slope repair on a piece of unused government property with a building, situated at the fringe of the country park, which the government has in principle agreed to rent out to them. They plan to use the place as an activity centre or office. The funds will also enable them to hire some staff of mainly retired people willing to be paid the minimum wage and to take out insurance for them. 
Table 1: Basic profile of the three MWGs

\begin{tabular}{|c|c|c|c|}
\hline & Fools' Paradise & Friendship Terrace & Chinese Herbal Garden \\
\hline $\begin{array}{l}\text { Establishment year or } \\
\text { date }\end{array}$ & $\begin{array}{l}24 \text { December } 1970 \text { (written on cement } \\
\text { plaque) }\end{array}$ & 1960s (oral history) & 1982/83 (oral history) \\
\hline Type & Recognized & Zoned & Enhanced \\
\hline $\begin{array}{l}\text { Country Park / } \\
\text { Year Designated / Size }\end{array}$ & $\begin{array}{l}\text { Kam Shan Country Park / } 1977 \text { / } 339 \\
\text { hectares }\end{array}$ & \begin{tabular}{|l|} 
Tai Tam Country Park, Quarry Bay \\
Extension / 1977 / 1,315 hectares
\end{tabular} & $\begin{array}{l}\text { Lung Fu Shan Country Park / } 1998 \text { / } \\
47 \text { hectares }\end{array}$ \\
\hline Location / Zone $^{7}$ & On a knoll; Zone 2 or 3 area & Hill slope; Zone 2 or 3 area & Hillside; Zone 2 or 3 area \\
\hline Estimated area size & 3,500 square meters (nearly one acre) & 200 square meters & 1,050 square meters \\
\hline Existing facilities & $\begin{array}{l}\text { Gardens; rain shelters; chin-up and } \\
\text { parallel bars; picnic tables; stove; } \\
\text { storage; mahjong table (fixed) and } \\
\text { plastic chairs; benches; plastic drums } \\
\text { to collect water for gardening }\end{array}$ & $\begin{array}{l}\text { Garden; rain shelter; stove, storage } \\
\text { and an area to collect mountain water; } \\
\text { a notice board; benches; clearing for } \\
\text { doing exercise; morning walkers } \\
\text { originally built a toilet facility but was } \\
\text { later demolished by the government } \\
\text { for health and hygiene reasons }\end{array}$ & $\begin{array}{l}\text { Garden; rain shelter; information } \\
\text { board; storage; stove; fish pond; some } \\
\text { exercise facilities; benches }\end{array}$ \\
\hline $\begin{array}{l}\text { Recreational, social, } \\
\text { and other activities }\end{array}$ & $\begin{array}{l}\text { Gardening; exercise; badminton; make } \\
\text { and drink tea; chit chat; listen to } \\
\text { music; write artistic characters; past } \\
\text { activities also include sword dance; } \\
\text { Tai Chi; mahjong }\end{array}$ & $\begin{array}{l}\text { Gardening; exercise; make and drink } \\
\text { tea; chit chat; past activities include } \\
\text { playing mahjong }\end{array}$ & $\begin{array}{l}\text { Gardening and planting Chinese herbs } \\
\text { for educational purposes; organize } \\
\text { training courses and guided tours; } \\
\text { exercise; badminton; raise carps; make } \\
\text { and drink tea; chit chat; past activities } \\
\text { include growing vegetables }\end{array}$ \\
\hline
\end{tabular}

$\overline{7}$ Zone 1 is for high intensity recreational area; Zone 2 for low intensity recreational area; and, Zone 3 for conservation area. 


\section{Analysis and Discussion}

\section{MWG as a unique form of guerilla gardening}

The type of guerilla gardening involved in this study occur on mountains and hillsides and involve other recreational and social purposes. Adams, Hardman and Larkham (2015: 1233) note that "guerrilla gardeners add value or make significant impacts on abandoned or neglected land or landscapes." Morning walkers contribute value enhancement or, in planning terms, to the 'betterment' of not just the area they occupy but also to the wider country park through their gardens, artistic inscriptions, and recreational facilities that are not provided elsewhere within the protected areas. Guerilla gardens have a social function (Reynolds, 2008), which morning walkers seem to manifest through their welcoming attitude and eagerness to provide tea, snacks, and a place of rest and to chit chat with other park users. This is in stark contrast to the anti-social behavior, which Adams, Hardman and Larkham (2015) observed as one of the drawbacks of guerilla gardening in some places. MWGs can have the potential of easing the problem of limited space for simple outdoor recreation in the densely built-up urban areas of Hong Kong. Facer (2013: 135) argues that the guerilla gardening movement is a creative way of everyday life to "make visible the creative possibilities of the present." Just as guerilla gardening in urban areas makes "visible the way in which a local street might be reimagined as a country park" (Facer, 2013: 141), guerilla gardening in the countryside can be creatively reimagined as a local street playground or community garden in a country park as a solution to some public need. Comparing the three case studies, morning walkers express no fear of losing their gardens through demolition because the gardens are in protected areas. However, zoned and enhanced gardens provide more sense of security than only recognized ones. Nevertheless, morning walkers expect garden users, as in the case of Fool's Paradise, to contribute to the upkeep of the garden. Failure to do so could result in receiving some cold or unwelcoming treatment. It is too early to speak about the embeddedness of MWGs in local governance structures in the same sense as Adams and Hardman (2014) observed about the transition to institutionalization of guerilla gardening activities in some places. But the idea of embeddedness, as observed during the study, is in some way reflected in the way government-built MWGs inside and outside protected areas are designed which incorporates the original concept of MWG.

Whether it was for reasons of equity that these gardens were allowed to continue to exist can be answered to some extent by observing their present situations in terms of the degree of property rights they enjoy with respect to their gardens. Guerilla-gardening morning walkers had started cultivating their gardens several years or even more than a decade before these areas were enclosed within protected areas. While officials may have had discovered these gardens before the introduction 
of the country park system in the late 1970s, the action taken was to have these gardens registered rather than be demolished. As described above, the land use of some of these gardens have evolved from registered to enhanced status. The approach taken by officials towards MWGs is considered as an important enabling factor for the emergence of informal forms of co-management between the government and users within country parks. The morning walkers enjoy three types of property rights in Schlager and Ostrom's (1992) bundle of rights framework: access, some degree of withdrawal and of management. Morning walkers are free to access their gardens. Except on Sundays and public holidays, they can even drive their cars into the country park to reduce distance and time to reach their gardens on foot. They can obtain certain products from the resource, specifically soil nutrients to grow their gardens and mountain water to make their tea. They can also take herbs or bloomed flowers home, unless they are spotted by other casual visitors earlier. In terms of managing the garden, they maintain existing facilities and keep the area clean.

\section{MWG as incipient co-management of natural resource}

While Premauer and Berkes (2015) emphasize formal arrangements of sharing of power and responsibilities between the state and local resource users, this paper takes into consideration the possibility of the existence of informal processes of power and responsibility sharing based on tacit understanding of rights and duties, and involving some degree of property rights. Formal partnership arrangements typically involve the setting up of a board of management where state and non-state representatives are equally represented, as well as funding embedded in the financial arrangements for a protected area (Ross et al, 2009). However, negotiations, decisions, implementation, and benefits can also take place in less formal processes. The three case studies show that a more participative approach to protected area management has the advantage or consequence of making land use changes possible (Rouillard et al, 2014). The land use evolution of MWGs represents the emergence of incipient forms of co-management of land resources. While it lacks institutional support, such informal partnership already entails some degree of devolution (Hoffman, 2009) of power and responsibility in terms of access, withdrawal, and management rights. Morning walkers play some degree of stewardship role over the garden they cultivate. Their gardens offer other park users a recreational experience not provided in other parts of the country park.

Furthermore, a comparison of the nature of partnership arrangement shows variations across the three MWGs in terms of their relationship with the government, the degree of property rights, and the level of sense of security. For example, based on observation, zoned and enhanced MWGs have similar degrees of incorporation into land use planning, and also these two types of MWGs seem to have a higher degree of incorporation in comparison to the recognized MWG. In other words, although all three gardens have been granted some degree of property rights, the recognized MWG enjoys less guarantee of not being demolished. As social rules that influence the 
nature of the actors' interrelationship with respect to property (Alchian \& Demsetz, 1973), the different degrees of property rights in terms of management rights observed in the case studies give rise to two general types of user relationship with the government. The relationship of the morning walkers of the recognized and zoned gardens with officials can be mainly characterized as compliant, while for those of the enhanced garden as collaborative. While the compliant type gives legitimacy to the regulatory regime (Hoffman, 2009; Andrade \& Rhodes, 2012), the demand for participation in decision-making is limited to issues that concern their gardens and the engagement with the government minimal. Their relationship with the government is focused on compliance with prohibitions and trying to avoid doing anything that could give officials reasons to kick them out. The collaborative type goes beyond mere compliance. They find ways to enhance the value of the garden and its surroundings, creating better outcomes for the country park as a whole. Their interaction with the government is more intense. Moreover, they seek ways to improve organizational capacity to overcome present limited funds and manpower.

Currently, the major issues faced by morning walkers are the lack of funds and participation. The morning walkers are in general struggling to maintain facilities in good condition. There is a lack of legal support for user participation in the management of MWGs. It follows that there is no financial structure for the sustainable management of MWGs. District councils have helped some of them in the past, but the lack of a formal agreement in terms of budgetary allocation of funds means that the availability of funds may change along with the change in priorities. If they express their needs, they may face the lack of responsiveness on the part of park officials, which relates to the issue of inadequate participation in decision-making (Essex, 1990). Under an informal type of co-management arrangement, they may also have to face the problems of leadership continuity (Sutton \& Rudd, 2014). In general, the sizes of various communities of morning walkers have dwindled due to age and migration. Fortunately, Fool's Paradise has several junior morning walkers. However, their commitment to the garden will still have to be seen when the original ones are gone. This may be less of an issue with regard to the Chinese Herbal Garden which has a more structured organization.

\section{Local resource user leadership as an enabling factor of MWG co-management}

Premauer and Berkes (2015) point out that co-management fosters communication and resolving conflicts through negotiations and trade-offs to balance conservation and the needs of local indigenous communities. The creation of protected areas affects the recreational activities of resource users (Kirkpatrick, 2001). The morning walkers of the three gardens demonstrated the capacity and willingness to compromise, particularly because it involves some degree of property rights in the form of permission for the garden to remain and for morning walkers to continue using it. Leadership is important to enable local user responsiveness to opportunities provided by the system. Mr. L of Friendship Terrace said, 
"The government built for us this rain shelter which is better than the one we built... We used to have a toilet in that corner but they asked us to remove it because of sanitation problems, and so we removed it."

At first, one may think the status of a garden (registered, recognized, or designated) depends on the country park zoning policy, that is, their location inside country parks. However, based on observation, while designated MWGs are generally located in Zone 1 areas, there are also recognized and designated gardens in Zone 2 areas. A possible explanation for the latter observation could be related to the nature of government-user relationship, but this requires deeper investigation. This study suggests user leadership as one of the plausible reasons. User leadership is essential to the success of co-management (Emerson \& Gerlak, 2014). The case studies show that different types of leadership based on motivations, attitudes, strategy of leaders can lead to different outcomes. A more adaptive type of leadership, willing to align concerns with the wider resource system and create networks to achieve goals can result in a closer and more intense collaboration with government in value enhancement of a garden (Chinese Herbal Garden). A conformist type of attitude, abiding by the rules for sense of security and establishing contact with officials to seek help can result in investment as a form of reward for compliance (Friendship Terrace). A more self-reliant type of attitude, following rules to avoid conflicts and keeping distance from officials provides limited partnership with government (Fool's Paradise).

\section{Research agenda and suggested recommendations}

A specific research agenda that could be interesting is to examine the relationship of co-management and transaction costs. Blore et al (2013) suggest the potential of co-management of reducing transaction costs, which would attract the attention of policy makers and academics, but much study is yet to be done to show this is the case. It is important to consider the overall net cost which covers not just the cost of institution building to support partnership arrangements (Blore et al, 2013) but other costs as well, such as the cost of rule enforcement, and so on. Other important areas that need further investigation is morning walkers' perceptions or levels of satisfaction of existing country park recreational facilities and their motivations for their guerilla gardening activities. Such research work could lead to policy recommendations that encourage fostering the local user participation in country park planning to make the design and siting of recreational facilities, as far as possible, sensitive to their needs and preferences.

Planning controls the relationship between people and environment. While planning control has its justifiable purposes, it should be done in the extent in which "planners can be more open to potentially "non-conforming" ideas of sustainable development" (Adams, Scott \& Hardman, 2013: 381). Thus, fostering morning walkers' 
involvement in becoming co-partners in achieving country park objectives is recommended. Specific actions to this end could include investment and innovation for MWG value enhancement to foster trust and collaboration and supporting incipient or informal co-management with formalized governance structures to facilitate attainment of objectives (Wang et al, 2012). On the part of morning walkers, they could be encouraged to formalize the structure of their communities, for example, by establishing a Society or Charity or Limited Company, with office bearers whose terms and responsibilities are clearly set out, and who are accountable with regard to the use of funds. This can foster user group leadership and continuity (Sutton \& Rudd, 2014). Then, it is recommended that the government establish a formal agreement with various groups to foster upward and downward accountability (Nagendra, Karmacharya \& Karna, 2005). Such formal arrangements can enhance the capacity for user participation and the ability of users to act as catalyzer for changes and improvements in the park. A major caveat of such endeavour is the general restrictiveness of the political process in Hong Kong (Scott, 2010) where a more open mind towards allowing a more direct public participation (Hung, 2015b) in land use planning and management would certainly be crucial. The Hong Kong case studies of countryside guerilla gardening in this paper have provided useful lessons on the importance of paying adequate attention to the social dimension of land use planning (Cilliers \& Timmermans, 2014), particularly with regard to issues of equity and to fostering user leadership and participation to harness the contributions that users can make to overall objectives.

\section{References}

ADAMS, D. \& HARDMAN, M. 2014. Observing guerrillas in the wild: Reinterpreting practices of urban guerrilla gardening. Urban Studies, 51, 1103-1119.

ADAMS, D., HARDMAN, M. \& LARKHAM, P. 2015. Exploring guerrilla gardening: gauging public views on the grassroots activity. Local Environment, 20, 1231-1246.

ADAMS, D., SCOTT, A. J. \& HARDMAN, M. 2013. Guerrilla warfare in the planning system: revolutionary progress towards sustainability? Geografiska Annaler: Series B, Human Geography, 95, 375-387.

AGRAWAL, A. \& OSTROM, E. 2001. Collective action, property rights, and decentralization in resource use in India and Nepal. Politics \& Society, 29, 485.

AKAMANI, K., WILSON, P. I. \& HALL, T. E. 2015. Barriers to collaborative forest management and implications for building the resilience of forest-dependent communities in the Ashanti region of Ghana. Journal of Environmental Management, 151, 11-21. 
ALCHIAN, A. A. \& DEMSETZ, H. 1973. The property right paradigm. The Journal of Economic History, 33, 16-27.

ALMUDI, T. \& BERKES, F. 2010. Barriers to empowerment: Fighting eviction for conservation in a southern Brazilian protected area. Local Environment, 15, 217-232.

ANDRADE, G. S. M. \& RHODES, J. R. 2012. Protected areas and local communities: An inevitable partnership toward successful conservation strategies? Ecology and Society, 17, 14-29.

ARCEO, H. O., CAZALET, B., ALIÑO, P. M., MANGIALAJO, L. \& FRANCOUR, P. 2013. Moving beyond a top-down fisheries management approach in the northwestern Mediterranean: Some lessons from the Philippines. Marine Policy, 39.

BERKES, F. 2004. Rethinking community-based conservation. Conservation Biology, 18, 621-630.

BERKES, F. 2009. Evolution of co-management: Role of knowledge generation, bridging organizations and social learning. Journal of Environmental Management, 90, 1692-1702.

BLOMLEY, N. 2004. Un-real estate: proprietary space and public gardening. Antipode, 36, 614-641.

BLORE, M. L., CUNDILL, G. \& MKHULISI, M. 2013. Towards measuring the transaction costs of co-management in Mkambati Nature Reserve, Eastern Cape, South Africa. Journal of Environmental Management, 129, 444-455.

BORRINI-FEYERABEND, G., KOTHARI, A. \& OVIEDO, G. 2004. Indigenous and Local Communities and Protected Areas: Towards Equity and Enhance Conservation. In: PHILLIPS, A. (ed.) Guidance on Policy and Practice for Co-managed Protected Areas and Community Conserved Areas. Gland, Switzerland and Cambridge, UK: International Union for Conservation of Nature and Natural Resources and Cardiff University.

BREWER, T. D. \& MOON, K. 2015. Towards a functional typology of small-scale fisheries co-management informed by stakeholder perceptions: A coral reef study. Marine Policy, 51, 48-56.

BRUCKMEIER, K., ELLEGARD, A. \& PIRIZ, L. 2005. Fishermen's interests and cooperation: pre-conditions for joint management for Swedish coastal fisheries. Ambio, 34, 101-110.

CILLIERS, E. J. \& TIMMERMANS, W. 2014. The importance of creative participatory planning in the public place-making process. 41, 413-429.

CLARK, J. R. A. \& CLARKE, R. 2011. Local sustainability initiatives in English National Parks: What role for adaptive governance? Land Use Policy, 28, 
314-324.

CLARVIS, M. H. \& ENGLE, N. L. 2015. Adaptive capacity of water governance arrangements: a comparative study of barriers and opportunities in Swiss and US states. Reg Environ Change, 15, 517-527.

CRANE, A., VISWANATHAN, L. \& WHITELAW, G. 2013. Sustainability through intervention: a case study of guerrilla gardening in Kingston, Ontario. The International Journal of Justice and Sustainability, 18, 71-90.

CUNDILL, G. \& RODELA, R. 2012. A review of assertions about the processes and outcomes of social learning in natural resource management. Journal of Environmental Management, 113, 7-14.

CUNDILL, G., THONDHLANA, G., SISITKA, L., SHACKLETON, S. \& BLORE, M. 2013. Land claims and the pursuit of co-management on four protected areas in South Africa. Land Use Policy, 35.

DIETZ, T., OSTROM, E. \& STERN, P. C. 2003. The struggle to govern the commons. Science, 302.

EMERSON, K. \& GERLAK, A. K. 2014. Adaptation in collaborative governance regimes. Environmental Management, 54, 768-781.

ESSEX, S. J. 1990. Woodland planning in the Peak District National Park, UK: formulation and implementation of a land use policy. Land Use Policy, 7, 243-256.

EVANS, L. S. 2010. Ecological knowledge interactions in marine governance in Kenya. Ocean and Coastal Management, 53, 180-191.

EVANS, L. S., HICKS, C. C., COHEN, P. J., CASE, P., PRIDEAUX, M. \& MILLS, D. J. 2015. Understanding leadership in the environmental sciences. Ecology and Society, 20, 50-67.

FABIAN, L. \& SAMSON, K. 2016. Claiming participation - a comparative analysis of DIY urbanism in Denmark. Journal of Urbanism, 9, 166-184.

FACER, K. 2013. The problem of the future and the possibilities of the present in education research. International Journal of Education Research, 61, 135-143.

FINN, D. 2014. DIY urbanism: implications for cities. Journal of Urbanism: International Research on Placemaking and Urban Sustainability, 7, 381-398.

FLORES, C. H. 2006. Food not Lawns: How to Turn Your Garden and Neighbourhood into a Community Chelsea Green, White River Function.

GERHARDINGER, L. C., GODOY, E. A. S. \& JONES, P. J. S. 2009. Local ecological knowledge and the management of marine protected areas in Brazil. Ocean and Coastal Management, 52, 154-165.

GETZNER, M. 2014. Governance and management strategies in national parks: 
implications for sustainable regional development. Int. J. Sustainable Society, 6.

GOLGER, O. J. 1972. Hong Kong: A problem of housing the masses. Ekistics, 33, 173-177.

GRAF, H. 2014. From Wasteland to Flower Bed: Ritual in the Website Communication of Urban Activist Gardeners. Culture Unbound. Journal of Current Cultural Research, 6, 451-471.

GRANEK, E. F. \& BROWN, M. A. 2005. Co-management approach to marine conservation in Moheli, Comoros Islands. Conservation Biology, 19, 1724-1732.

HAYNES, C. 2013. Seeking control: disentangling the difficult sociality of Kakadu National Park’s joint management. Journal of Sociology, 49, 194-209.

HEIM LAFROMBOIS, M. 2015. Blind spots and pop-up spots: A feminist exploration into the discourses of do-it-yourself (DIY) urbanism. Urban Studies, DOI 10.1177/0042098015604078.

HOFFMAN, D. M. 2009. Institutional legitimacy and co-management of a marine protected area: Implementation lessons from the case of Xcalak Reefs National Park, Mexico. Human Organization, 68, 39-54.

HORIGUE, V., ALIÑO, P. M., WHITE, A. T. \& PRESSEY, R. L. 2012. Marine protected area networks in the Philippines: Trends and challenges for establishment and governance. Ocean and Coastal Management, 64, 15-26.

HUNG, H. 2015a. Field study of five "paradises" within Kam Shan Country Park. Survey and Built Heritage, 24, 63-82.

HUNG, H. 2015b. Governance of built-heritage conservation in a restrictive political system: The involvement of non-governmental stakeholders. Habitat International, 50, 65-72.

JIM, C. Y. 1986. The country parks programme and countryside conservation in Hong Kong. The Environmentalist, 6, 259-270.

KEPE, T. 2008. Land claims and co-management of protected areas in South Africa: Exploring the challenges. Environmental Management, 41, 311-321.

KIMDUNG, N., BUSH, S. \& MOL, A. P. J. 2013. Administrative co-management: The case of special-use forest conservation in Vietnam. Environmental Management, 51, 616-630.

KIRKPATRICK, J. B. 2001. Ecotourism, local and indigenous people, and the conservation of the Tasmanian Wilderness World Heritage Area. Journal of the Royal Society of New Zealand, 31, 819-829.

LYONS, K. 2014. Urban Food Advocates' tactics to rebuild food systems: 
Convergence and divergence in food security and food sovereignty discourses. Dialogues in Human Geography, 4, 212-217.

MACLEAN, K., CUTHILL, M. \& ROSS, H. 2014. Six attributes of social resilience. Journal of Environmental Planning and Management, 57, 144-156.

MACLEAN, K., ROSS, H., CUTHILL, M. \& RIST, P. 2013. Healthy country, healthy people: An Australian Aboriginal organisation's adaptive governance to enhance its social-ecological system. Geoforum, 45, 94-105.

MANOLIS, J. C., CHAN, K. M., FINKELSTEIN, M. E., STEPHENS, S., NELSON, C. R., GRANT, J. B. \& DOMBECK, M. P. 2008. Leadership: A new frontier in conservation science. Conservation Biology, 23, 879-886.

MASCIA, M. B. \& CLAUS, C. A. 2008. A property rights approach to understanding human displacement from protected areas: A case of marine protected areas. Conservation Biology, 23, 16-23.

MBURU, J. \& BIRNER, R. 2007. Emergence, adoption, and implementation of collaborative wildlife management or wildlife partnerships in Kenya: A look at conditions for success. Society and Natural Resources, 20, 379-395.

MEHRING, M., SEEBERG-ELVERFELDT, C., KOCH, S., BARKMANN, J., SCHWARZE, S. \& STOLL-KLEEMANN, S. 2011. Local institutions: regulation and valuation of forest use - Evidence from Central Sulawesi, Indonesia. Land Use Policy, 28, 736-747.

NAGENDRA, H., KAMACHARYA, M. \& KARNA, B. 2005. Evaluating forest management in Nepal: views across space and time. Ecology and Society, 10, 24-39.

NAMARA, A. 2006. From Paternalism to Real Partnership with Local Communities? Experiences from Bwindi Impenetrable National Park (Uganda). Africa Development, XXXI, 37-66.

OLSSON, P., FOLKE, C. \& BERKES, F. 2004. Adaptive comanagement for building resilience in social-ecological systems. Environmental Management, 34, 75-90.

OLSSON, P., GUNDERSON, L. H., CARPENTER, S. R., RYAN, P., LEBEL, L., FOLKE, C. \& HOLLING, C. S. 2006. Shooting the rapids: navigating transitions to adaptive governance of social-ecological systems. Ecology and Society, 11, 18-38.

PINKERTON, E. (ed.) 1989. Cooperative Management of Local Fisheries: New Directions for Improved Management and Community Development, Vancouver: University of British Columbia Press.

PLUMMER, R. \& ARMITAGE, D. 2007. Crossing boundaries, crossing scales: The evolution of environmental and resource co-management. Geography 
Compass, 1, 834-849.

PREMAUER, J. M. \& BERKES, F. 2015. A pluralistic approach to protected area governance: Indigenous Peoples and Makuira National Park, Colombia. Ethnobiology and Conservation, 4, 1-16.

RALSTON, S. J. 2012. Educating future generations of community gardeners: a Deweyan challenge. Critical Education, 3, 1-17.

REYNOLDS, R. 2008. On guerrilla gardening: a handbook for gardening without permission, London, Bloomsbury.

ROSS, H., GRANT, C., ROBINSON, C. J., IZURIETA, A., SMYTH, D. \& RIST, P. 2009. Co-management and Indigenous protected areas in Australia: Achievements and ways forward. Australasian Journal of Environmental Management, 16, 242-252.

RUIZ-MALlÉN, I., SCHUNKO, C., CORBERA, E., RÖS, M. \& V., R.-G. 2015. Meanings, drivers, and motivations for community-based conservation in Latin America. Ecology and Society, 20, 33-46.

SBICCA, J. 2014. The need to feed: urban metabolic struggles of actually existing radical projects. Critical Sociology, 40, 817-834.

SCHLAGER, E. \& ELINOR, O. 1992. Property-rights regimes and natural resources: a conceptual analysis. Land economics, 68, 249-262.

SCOTT, I. 2010. The Public Sector of Hong Kong, Hong Kong, Hong Kong University Press.

SECRETARY FOR ENVIRONMENT 1975. Draft of the Drafting Instructions, Regulations and By-laws (Memorandum, 30 June 1975).

SHEPARD, B. 2014. DIY urbanism as an environmental justice strategy: the case study of Time's Up! 1987-2012. TIA, 7, 42-73.

SMART, A. 2001. Unruly places: urban governance and the persistence of illegality in Hong Kong's urban squatter areas. American Anthropologist, 103, 30.

SMITH, S. L. 2012. Toward inclusive co-management: factors influencing stakeholder participation. Coastal Management, 40, 327-337.

SUTTON, A. M. \& RUDD, M. A. 2014. Deciphering contextual influences on local leadership in community-based fisheries management. Marine Policy, 50, 261-269.

TALBOT, L. M. 1965. Conservation of the Hong Kong countryside: summary report and recommendation by Lee M. Talbot and Martha H. Talbot, Hong Kong, Hong Kong: Government Printer.

TORQUEBIAU, E. \& TAYLOR, R. D. 2009. Natural resource management by rural citizens in developing countries: innovations still required. Biodivers Conserv, 
$18,2537-2550$.

VOKOU, D., DIMITRAKOPOULOS, P., JONES, N., DAMIALIS, A., MONOKROUSOS, N., PANTIS, J. \& MAZARIS, A. 2014. Ten years of co-management in Greek protected areas: an evaluation. Biodiversity and Conservation, 23, 2833-2855.

WANG, G., INNES, J., WU, S., KRZYZANOWSKI, J., YIN, Y., DAI, S., ZHANG, X. \& LIU, S. 2012. National park development in China: conservation or commercialization? A Journal of the Human Environment, 41, 247-261.

WEVER, L., GLASER, M., GORRIS, P. \& FERROL-SCHULTE, D. 2012. Decentralization and participation in integrated coastal management: Policy lessons from Brazil and Indonesia. Ocean and Coastal Management, 66, 63-72.

WONG, F. Y. 1997. Recreational use of Hong Kong country parks: An analysis of patterns and demands. University of Hong Kong. 